\title{
Guidelines for assessing the valorization of a waste into cementitious material: dredged sediment for production of self compacting concrete
}

\author{
F. Rozas, A. Castillo, I. Martínez, M. Castellote $\bowtie$ \\ Institute of Construction Science "Eduardo Torroja" (IETcc-CSIC) (Madrid, Spain) \\ \martaca@ietcc.csic.es
}

\author{
Received 17 December 2013 \\ Accepted 28 January 2015 \\ Available on line 04 May 2015
}

\begin{abstract}
This article presents some guidelines in order to analyse the feasibility of including a waste material in the production of a structural cementitious material. First of all, the compatibility of the waste with a cementitious material has to be assured; then, if necessary, a decontamination step will be carried out; after, decision on the type of material has to be taken based on different aspects, with special emphasis on the granulometry. As a last step, mechanical, environmental and durability properties have to be evaluated. Then the procedure is illustrated with a full example, obtaining a self compacting concrete (SCC) including dredged sediment taken from a Spanish harbour.
\end{abstract}

KEYWORDS: Protocol; Waste treatment; Cementitious material; Dredged sediment; Self-compacting concrete

Citation/Citar como: Rozas, F.; Castillo, A.; Martínez, I.; Castellote, M. (2015) Guidelines for assessing the valorization of a waste into cementitious material: dredged sediment for production of self compacting concrete. Mater. Construcc. 65 [319], e057 http://dx.doi.org/10.3989/mc.2015.10613.

\begin{abstract}
RESUMEN: Directrices para evaluar la puesta en valor de un residuo en la fabricación de un material base cemento: producción de hormigón autocompactante a partir de sedimentos dragados. Este artículo presenta algunas directrices con el fin de analizar la posibilidad de incluir un material de desecho en la producción de un material base cemento estructural. En primer lugar, debe asegurarse la compatibilidad de los residuos con el material base cemento. Tras ello, si es necesario, se llevará a cabo la etapa de descontaminación del residuo. Después debe tomarse la decisión sobre el tipo de material a utilizar en base a diferentes aspectos, haciendo especial énfasis en la granulometría. Como último paso, deben evaluarse las propiedades mecánicas, ambientales y de durabilidad del producto final. El procedimiento a seguir se ilustra con un ejemplo concreto basado en la obtención de un hormigón autocompactante (SCC) incluyendo en su fabricación sedimentos dragados tomados de un puerto español.
\end{abstract}

PALABRAS CLAVE: Protocolo; Tratamiento de residuos; Material cementíceo; Sedimento dragado; Hormigón autocompactante

Copyright: (C) 2015 CSIC. This is an open-access article distributed under the terms of the Creative Commons Attribution-Non Commercial (by-nc) Spain 3.0 License.

\section{INTRODUCTION}

In the last years, lot of research has been done in including wastes into concrete, mainly for secondary uses but also trying to accomplish with structural performance. As an example, a bibliographic search have been done in the Web of Science, looking for "concrete" and "waste" within the topic, in all domains of science and including all the years in the repository until October 2014.
Within these results, filters were applied to include different kind of wastes, as are "dredged sediment", and other wastes more typically used in concrete fabrication, as "industrial", "agricultural" or "demolition" among others (1-10). The results are given in Figure 1, where it can be deduced that even though there are a lot of contributions in this area, and society concerns about the reutilization of waste in concrete fabrication, the research is mainly focused on the reuse of several wastes, as 


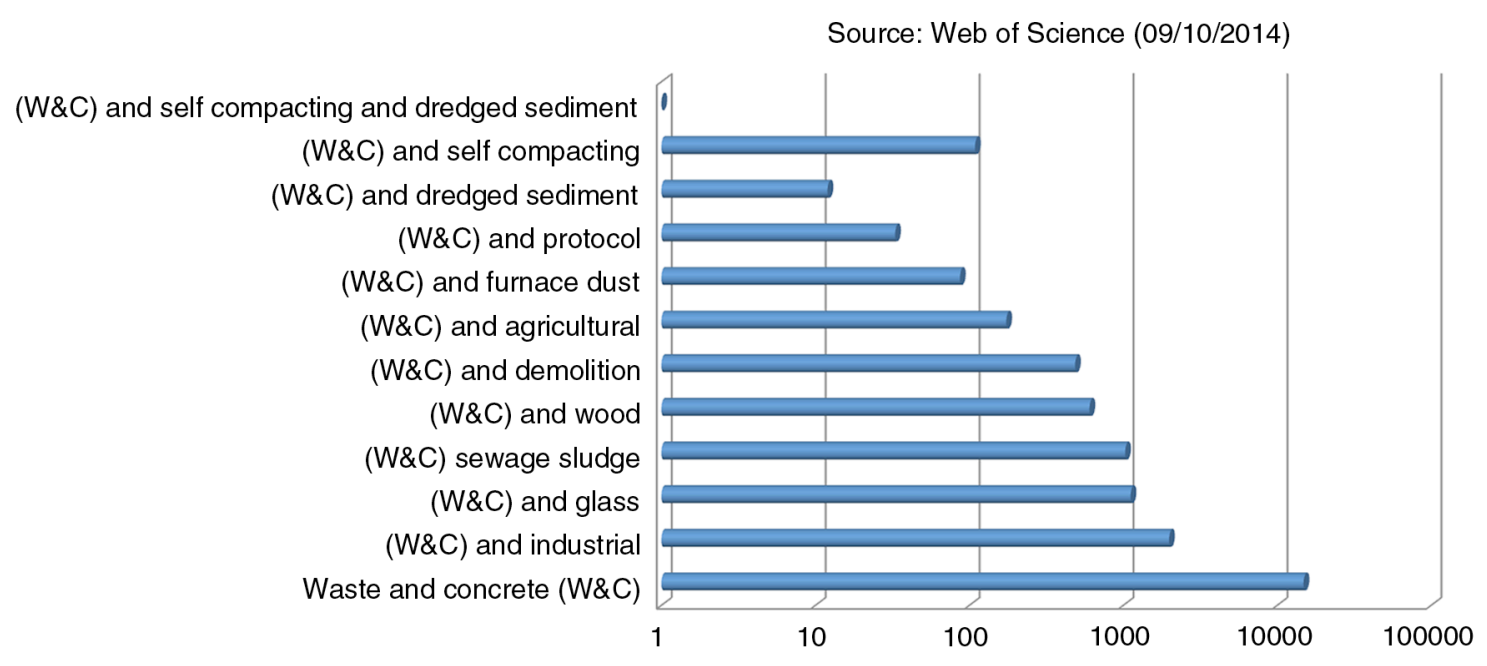

FIGURE 1. Results from the bibliographic search in Web of Science.

industrial, demolition or glass, for most abundant. Only 12 papers were found for the topic including dredged sediments as a waste to be use in concrete fabrication, and no one is found for the use of dredged sediments in self compacting concrete. It is remarkable that no general rules, as established protocols, are found in the bibliography. In this way, there are no previous efforts in order to systematically evaluate and decide on the feasibility for including a waste into a cementitious matrix.

Even thought 33 papers were found including the words "waste + concrete + protocol", after its examination, only one tried to reflect a real protocol (11), but it was based in the reuse of demolition materials, nothing to do with the scope of this paper.

It is also remarkable that the research in the area of reusing materials for self compacting concrete (SCC) started in the last decade (12-14), and has increased very fast in the last years with interesting contributions $(1-3,15-24)$, so, the necessity of some guidelines to assess the inclusion of these wastes in $\mathrm{SCC}$ is clear.

Filling this gap is the objective undertaken in this paper, which presents general guidelines to be followed in order to analyse the feasibility of including a waste material in the production of one of the most widely used building materials: concrete.

These guidelines have been illustrated on the basis of using dredged material in performing SCC. This is an interesting case study, as no bibliography has been found on it. Dredged sediment has been chosen because dredging is necessary to create and maintain navigation channels in naval facilities, and despite several hundred million cubic meters of sediment dredged each year just in U.S. most of this dredged material is disposed in open water, confined disposal facilities, and upland disposal facilities, not having so much research dedicated to, as reflected in the bibliographic results showed in Figure 1. In addition, in U.S., consistent with the National Dredging Policy, EPA encourages the "beneficial reuse" of dredged material. In Europe, having the same problem, according to new European Union Directives, mainly the EU Water Framework Directive, it is necessary to find an environmental solution to these materials. Dredged sediments have to be seen as a valuable resource better than a waste.

The reason for choosing SCC as the product to be constructed has been derived from the characteristics of the waste, taking into account its special characteristics in relation with their intrinsic environmental friendly technology: is able to flow by its own weight, eliminating the need of vibration, which can be translated into substantial reduction in energy, labour cost and construction time. Additionally, it contributes to a better working environment by eliminating the impact of noise and vibration as well as a making more comfortable the periods of works for the affected society.

\section{GUIDELINES FOR ASSESSING THE VALORISATION OF THE WASTE}

The scheme proposed and designed to assess the feasibility of a waste material to be incorporated in a cementitious material is given in Figure 2.

- Step 1: First of all, the waste material has to be subjected to a thorough chemical and mineralogical analysis in order to establish their elemental composition compatibility with a cementitious material. This is a very important step in the process, as if compatibility is not clear, it will be discarded for this type of valorisation.

- Step 2: If the composition of the waste is compatible with cement, hazardous characterization 


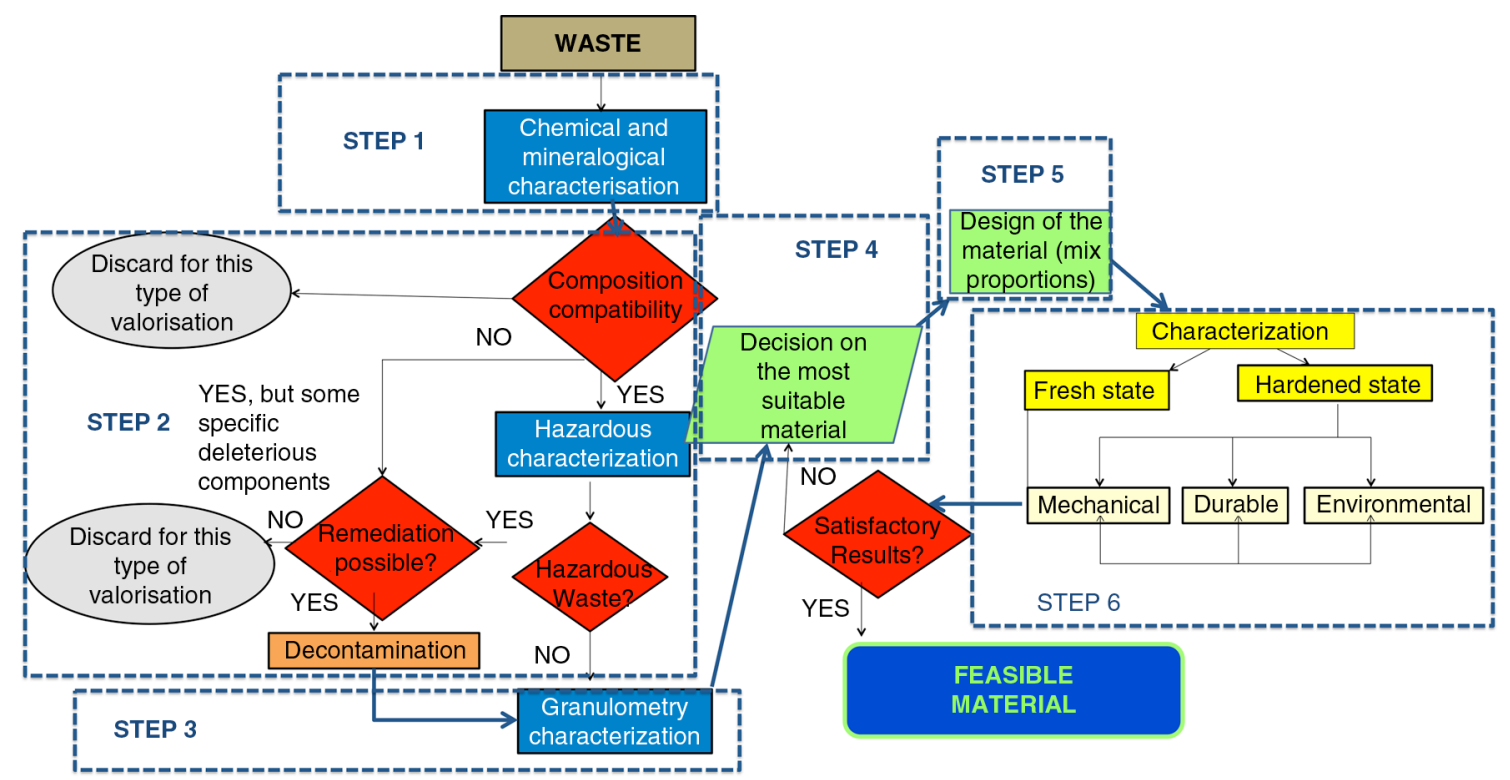

FIGURE 2. Schema of the protocol to be followed to investigate the feasibility of reusing a waste material as a component of a cementitious material.

of the waste has to be carried out. According to the definition, characteristic hazardous or toxic wastes are determined by evaluating their ignitability, corrosivity, reactivity, and toxicity. If they do not accomplish with these requirements, the following question is: it is possible to remediate it? This is quite important in the case of toxicity, with wastes having heavy metals and organic pollutants, which is the most frequent case. Different techniques to remediate contaminated wastes can be found in literature, for example, electrokinetic remediation (25-27). The same apply for components non hazardous but deleterious for the use: for example chlorides for reinforced concrete (28-30).

- Step 3: As a third step, it is necessary to carry out a thoroughly granulometric characterization.

- Step 4: Having material and hazardous compatibility assured, in function of composition and granulometry characteristics, the most suitable material to be produced, that includes it, has to be established to be decided.

- Step 5: The following step is the design of the material chosen with traditional components and including the waste, trying always to introduce the highest amount of waste compatible with the expected use.

- Step 6: After having designed the initial mix, according to the results obtained in the previous steps, the specimens have to be analysed both in fresh and in hardened state, where mechanical and environmental characteristics of the concrete, together with its durability properties have to be evaluated.
If results of step 6 are satisfactory, the material designed is feasible. If not, it is necessary to go again to step 4 and reconsider the type of material to fabricate.

\section{EXPERIMENTAL PROCEDURE: APPLICATION TO THE DREDGED MATERIAL}

\subsection{Characterization of the dredged materials}

The dredged material used in this research has been real non polluted marine dredged sediment taken from a Spanish Mediterranean harbour. After dredging, the material was stored under controlled conditions. Previous works about the characterization of these materials had been taken into account (31-34).

The composition of the dredged sediment used in this investigation was characterized on elemental composition by chemical analysis. The mineralogical determination was carried out by X-Ray diffraction.

Metal determination was carried out by inductively coupled plasma atomic emission spectroscopy (ICP-AES), also referred to as inductively coupled plasma optical emission spectrometry (ICP-OES), has been use on this propose. ICP-AES is an analytical technique used for the detection of trace metals in the environment.

ICP-AES allows detecting metals in all matrix, including soils water, aquosus samples, sediments, but a previous digestion is required $(\mathrm{Al}, \mathrm{Ba}, \mathrm{B}$, $\mathrm{Cu}, \mathrm{Fe}, \mathrm{Mn}, \mathrm{Zn}, \mathrm{Cd}, \mathrm{Ni}, \mathrm{Pb}, \mathrm{Ca}, \mathrm{Mg}, \mathrm{K}, \mathrm{Na}$, etc.). 
For the measurements of metals like $\mathrm{As}, \mathrm{Hg}, \mathrm{Sn}, \mathrm{Se}$, $\mathrm{Sb}$ and $\mathrm{Bi}$, a coupled hydride generation is used.

All the analysis were carried out by an external accredited laboratory following a regular protocol. The detection limits of the techniques are shown in Table 1.

For the ICP-AES determinations, a high frequency generator feeds an induction coil that produces a strong magnetic field. Argon flow is introduced into this magnetic field through a quartz torch located inside the coil. Argon is heated and ionized to form plasma (ionized gas sufficiently to conduct electrical energy).

A pneumatic nebulizer transforms liquid sample into an aerosol that is injected into the centre of the inductively coupled plasma (ICP). At the temperature reached $(10.000 \mathrm{~K})$ many atoms are excited and emit a characteristic spectrum at wavelengths determined for each element wave.

All the analysis for sediment physical and chemical characterization were made according to Spanish recommendations for dredged materials and following the recommended protocols (31). The dry weight fraction was determined by weight loss at $105^{\circ} \mathrm{C}$. For the rest of analyses, sediments were dried at $40{ }^{\circ} \mathrm{C}$ for $24 \mathrm{~h}$.

Additionally, physical characterization (granulometric analyses) and determination of the total organic content (TOC) was carried out. Grain size distribution followed UNE 103101 and total organic carbon (TOC) content was estimated by loss of ignition (LOI, determined heating the sample during 15 minutes at the temperature of $950{ }^{\circ} \mathrm{C} \pm 25^{\circ} \mathrm{C}$ ) and gravimetric determination as recommended for small dredged volumes and applying the following expression to express the results as total organic carbon.

TOC $\left(\mathrm{g} \mathrm{kg}^{-1}\right)=0,35 \mathrm{LOI}\left(\mathrm{g} \mathrm{kg}^{-1}\right)$

It was analysed in order to assess the presence of heavy metals, polycyclic aromatic hydrocarbons

TABLE 1. Detection limits for the techniques used for metal composition (ICP-AES) and mineralogical composition (chemical analysis)

\begin{tabular}{lcll}
\hline $\begin{array}{l}\text { Metal composition } \\
\text { (Detection limits, }\end{array}$ mg/kg) & \multicolumn{2}{c}{$\begin{array}{l}\text { Mineralogical composition } \\
\text { (Detection limits, \%) }\end{array}$} \\
\hline $\mathbf{A s}$ & 0.1 & $\mathrm{SiO}_{2}$ & 0.02 \\
$\mathbf{H g}$ & 0.1 & $\mathrm{Al}_{2} \mathbf{O}_{3}$ & 0.1 \\
$\mathbf{C d}$ & 2 & $\mathrm{Fe}_{2} \mathbf{O}_{3}$ & 0.01 \\
$\mathbf{C r}$ & 2 & $\mathbf{C a O}$ & 0.1 \\
$\mathbf{C o}$ & 2 & $\mathbf{M g O}$ & 0.1 \\
$\mathbf{N i}$ & 2 & $\mathbf{N a}_{2} \mathbf{O}$ & 0.01 \\
$\mathbf{P b}$ & 10 & $\mathbf{K}_{2} \mathbf{O}$ & 0.01 \\
$\mathbf{Z n}$ & 2 & $\mathbf{S O}_{3}(\mathbf{S c})$ & 0.01 \\
& & $\mathbf{T i O}_{2}$ & 0.03 \\
\hline
\end{tabular}

(PAHs), organophosphorous pesticides and other organic chlorinated compounds. These analyses are made using the fraction with particle size lower than $63 \mu \mathrm{m}$.

\subsection{Fabrication of the concrete specimens}

Concrete was cast with cement type I 42.5R without additions. Other components, apart from the sediment were water, sand and coarse aggregates. Three different mixes were tested. Its composition is shown in Table 2.

\subsection{Characterization of the concrete}

In fresh state, the fluency of the concrete was characterized through the slump test using the Abram's cone and the consistency of the concrete was measured following the UNE EN 12350-2 standard (35) by measuring the spread of the concrete on a flat plate subjected to a shocking movement. It was also followed the UNE EN 12350-8 standard (36), suitable for SCC. The density of the fresh concrete was measured according to the UNE EN 12350-6 standard (37). Another important parameter is the entrapped air of the concrete, which was determined through by means of the standard UNE EN 12350-7 (38).

In hardened state it was analyzed from the point of view of its mechanical, environmental and durable properties: From the mechanical point of view, compressive strength tests were carried out following the standard UNE-EN 12390-3 (39).

From an environmental point of view, leaching tests were carried out following the standard EN 12457-2:2002 (40). This test involves immersing the sample at a specified leachant volume in order to extract the components of the material. The solid residue is separated by filtration and an aliquot of the leachate is taken and analysed following the standards UNE ENV 12506 (41) and UNE ENV 13370 (42).

The durability properties were evaluated by analysis of porosity, pore size distribution and density

TABLE 2. Details of the mixes composition

\begin{tabular}{lrrc}
\hline Mix & A & \multicolumn{1}{c}{ B } & C \\
\hline Cement I 42,5 R & 420 & 450 & 450 \\
Dredged material & 73 & 80 & 100 \\
water & 205 & 202 & 202 \\
w/c & 0.49 & 0.45 & 0.45 \\
Silicious coarse aggregate (6/12) & 717 & 676 & 667 \\
Silicious sand (0/6) & 850 & 870 & 859 \\
Admixture I & 9.24 & 7.1 & \\
Admixture II & & & 7.425 \\
\hline
\end{tabular}


in two specimens by mercury intrusion porosimetry (MIP), using a Micromeritics 9320 Porosimeter. Also, the crystalline phases of the concrete have been analysed in duplicate powdered samples by X-Ray diffraction using a diffractometer model D8 Advance of Bruker AXS. Other indicator of durability is the electrical resistivity, which was measured by means of a commercial resistivimeter. Additionally, two different experiments to evaluate transport properties through the matrix were carried out: the first one was the measurement of the steady and non-steady state chloride diffusion coefficients and the other was capillary absorption. The steady (Ds) and non-steady (Dns) state chloride diffusion coefficients were determined using the multi-regime method (30) standardized as UNE 83987-2009 (43). The water take-up of hardened concrete was determined by capillary absorption. This method was standardized as UNE 83982:2008 (44).

All the procedures followed can be found in the mentioned bibliographic references.

\section{RESULTS AND DISCUSSION}

\section{Step 1: Chemical and mineralogical characterization of the dredged material}

Elemental composition of the original sediment, and on the fractions smaller than $2 \mathrm{~mm}$ and smaller than $63 \mu \mathrm{m}$ (sand + fine and fine fractions) are given in Table 3, where it can be seen that the major component is silicon oxide followed by calcium carbonate in all the different fractions analysed. Loss of material by calcination (LOI, lost of ignition)

TABLE 3. Characterization of the main components of the sediment. Loss of material by calcination/ignition (LOI -15 minutes at the temperature of $950{ }^{\circ} \mathrm{C} \pm 25^{\circ} \mathrm{C}$ )

\begin{tabular}{lcrr}
\hline & Original sediment & $<\mathbf{~} \mathbf{~ m m}$ & $<\mathbf{6 3} \boldsymbol{\mu m}$ \\
\hline $\mathrm{SiO}_{2}$ & 70.6 & 71.9 & 68.5 \\
$\mathrm{Al}_{2} \mathbf{O}_{3}$ & 5.1 & 4.7 & 5 \\
$\mathrm{FeO}$ & 2.3 & 2.2 & 2.0 \\
$\mathbf{C a O}$ & 0 & 0 & 0 \\
$\mathrm{CaCO}_{3} \%$ & 26.3 & 27.4 & 34.2 \\
$\mathrm{MgO}$ & 2.3 & 2.6 & 2.1 \\
$\mathrm{Na}_{2} \mathbf{O}$ & 1.5 & 1.2 & 0.93 \\
$\mathrm{~K}_{2} \mathbf{O}$ & 2.0 & 1.1 & 1.6 \\
$\mathrm{TiO}_{2}$ & 0.24 & 0.24 & 0.43 \\
$\mathrm{SO}_{2}$ & 0.11 & 0.07 & 0.11 \\
Loss of material by & & & \\
$\quad$ calcination & 16 & 16 & 20 \\
Humidity & 21.9 & & \\
Solid concentration & 78.1 & & \\
TOC (\% ) & & 4.1 & \\
\hline
\end{tabular}

was also determined heating the sample during 15 minutes at the temperature of $950{ }^{\circ} \mathrm{C} \pm 25^{\circ} \mathrm{C}$.

This composition has been confirmed by X-ray diffraction, where presence of quartz and calcite are the main components. Silicates of Fe and $\mathrm{Mg}$ are also present, dolomite, Fe and Ti sulphate, complex chlorides including different species, iron, and some clay (chamosite) in small proportions have also been identified. Expansive clays of the group of philosilicates (montmorillonite, saponite, nontronite, bentonite sepiolite and palygorskite), have been looked for specifically, not having been identified in the sediment.

Therefore, the sediment is compatible with cementitious materials.

Concerning $\mathrm{pH}$ of the sediment, $1 \mathrm{~g}$ of sediment suspended in $100 \mathrm{ml}$ deionized water, gives a $\mathrm{pH}$ in the solution of 8.5, which, as expected, implies alkaline $\mathrm{pH}$ compatible with cementitious materials.

Therefore, it is possible to go ahead to step 2.

\section{Step 2: Hazardous characterization of the waste}

The dredged sediment is a mineral waste that is not ignitable, corrosive or reactive. So, the point to analyse from a hazardous point of view is the toxicity. There are different recommendations and or environmental limits concerning discharge of dredged sediments to the sea. According to the Spanish recommendations for the management of dredged material in the Spanish harbours (31), toxicologically, the dredged sediments can be divided into three categories in function of their relative values concerning two levels of action: level 1 and level 2.

Category I: their effects on the marine flora and fauna are null or negligible. Therefore, these sediments can be discharged into the sea considering only mechanical effects. For this category, the level of contaminants is smaller than the level of action 1.

Category II: Moderated amount of contaminants. They could be discharged into the sea in a controled way. For this category, the level of contaminants is higher than the level of action 1 but smaller than the level of action 2 .

Category III: Dredged materials highly contaminated. They must be isolated from the sea or remediated accordingly. For this category, the level of contaminants is higher than the level of action 2 .

In terms of toxic substances contained in the material, the chemical characterization of pollutants was done over the fraction smaller than $63 \mu \mathrm{m}$, where they accumulate. The results obtained by ICP-AES, as well as the level of action 1 and 2 specified in (31) are given in Table 4, were it can be seen that the sediment corresponds to Category I, 
TABLE 4. Toxicological characterization of the dredged material. Results are given by $\mathrm{mg} / \mathrm{Kg}$ of dry material

\begin{tabular}{llcc}
\hline $\mathbf{m g} / \mathbf{K g}$ & \multicolumn{1}{c}{$\mathbf{6 3} \boldsymbol{\mu \mathbf { m }}$} & Level $\mathbf{~}$ & Level 2 \\
\hline Mercury & 0.21 & 0.6 & 3.0 \\
Cadmiun & 1.5 & 1.0 & 5.0 \\
Lead & 11.0 & 120 & 600 \\
Copper & 8.5 & 100 & 400 \\
Zinc & 150 & 500 & 3000 \\
Chromiun & 30.5 & 200 & 1000 \\
Nickel & 9.5 & 100 & 400 \\
PCB (28, 52, 101 118, 138, 153 y 180 IUPAC) & $<0.03$ & 0.03 & 0.1 \\
Arsenic & 6.6 & 80 & 200 \\
Total PCB & $<0.03$ & & \\
Oils and fats & 502 & & \\
Clorinated organic pesticides & $<0.05$ (each) & & \\
Organic extractable compounds & & & \\
Total polycyclic aromatic hydrocarbons (PAHs) & $<0.05$ (each) & \\
Organophosphorus pesticides & $<0.5$ (each) & & \\
Tin organic compounds & $<0.01$ (each) & & \\
Total petroleum hydrocarbons & $<5$ & \\
\hline
\end{tabular}

except in the case of cadmium, with a concentration corresponding to the category of slightly polluted (31). Additionally, bacteriological analysis on the water supernatant on the sediment gave a total count of Coli-form bacteria: $0 \mathrm{ufc} / 100 \mathrm{ml}$ and also for Faecal streptococcus: 0 ufc/100 ml.

Therefore, the material can be considered as is not hazardous and does not need to be decontaminated as a previous step in its reutilization procedure.

\section{Step 3: Granulometric characterization}

The granulometric distribution of the dredged sediment has been carried out according to UNE 103-102, by sedimentation, and is illustrated in Figure 3. The deposits belong preferably to the sand fraction between $2 \mathrm{~mm}$ and $63 \mu \mathrm{m}(94 \%)$. The clay and silt fraction reaches $5 \%$. In this figure, the values obtained in the granulometric analysis of the sediment are also compared with the limit values of the fine aggregates for concrete (45) and that of the filler for SCC concretes. From this figure, it can be deduced that the sediment is finer than the fine arid limits, not being finer enough as to be filler for SCC.

\section{Step 4: Decision on the most suitable material, including the waste, to be produced}

Considering the composition of the sediment, but mainly their granulometric characteristics (beyond the limits of fine aggregates) it has been chosen as a first option, trying to make self compacting concrete, SCC. This decision has also been motivated for the novelty, as seen in the bibliographic search, and for the high added value that it would suppose.

\section{Step 5: Design of the material}

First of all, it has to be pointed out that the intention of this step is not to optimise the mix of SCC, but to demonstrate the feasibility of their production with this waste on the basis of their properties. Therefore, provided the granulometry of the sediment, it could be used as a partial substitution of fine aggregates or as quasi-filler, with addition of more fines.

\subsection{Trials using the sediment as substitution of fine aggregate}

The design of the sample started replacing $8 \%$ of the fine aggregate with dredged sediment, in relation with a conventional concrete (mix A in Table 2). The cement type used was I $42.5 \mathrm{R}$ without additions. The particle size was $6 / 12$ for the coarse aggregate and $0 / 6$ for the sand. After several trials for optimization, the concrete obtained contained $420 \mathrm{Kg} / \mathrm{m}^{3}$ of cement with a water/cement ratio of 0.49 and a consistency of 12 . In fresh state the behaviour of this concrete was good, however, owing to the high content of fine arid and therefore its high demand of water, it was not so cohesive and not very fluid (see Figure 4). This behaviour was confirmed with the data obtained in the compressive strength measured at the age of 28 days. These data show an average value of $34 \mathrm{MPa}$. Without using the sediment this value is close to $40 \mathrm{MPa}$. 


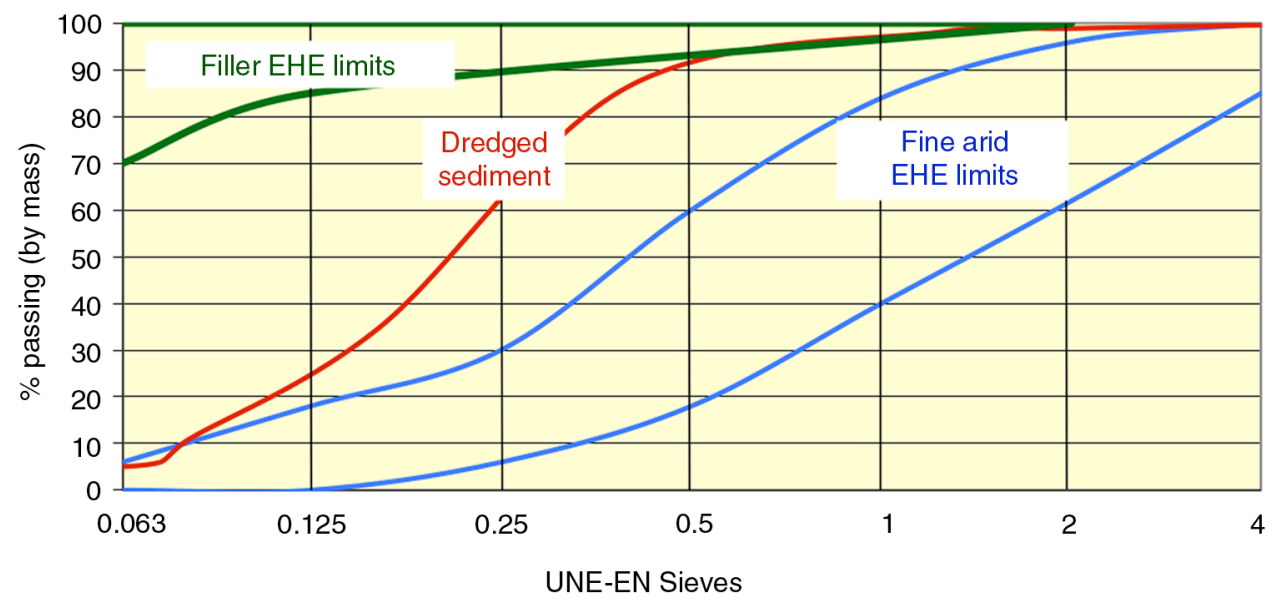

FIGURE 3. Granulometric analysis of the sediment and comparison with EHE-08 limits.

\subsection{Trials using the sediment as filler}

According to the results obtained in the preliminary tests, the possibility of reusing the sediment as a part of the filler instead of using it in the replacement of fines was evaluated.

Several tests were done with the same siliceous aggregate previously used, $450 \mathrm{Kg}$ of cement with a water/cement ratio of 0.45 and $80 \mathrm{Kg}$ of dredged material (mix B in Table 2). The behaviour observed for this mixture was very close to the fluidity, with the consistency of a self compacting concrete but without achieving the typical characteristics of this material since the spread diameter was $33 \mathrm{~cm}$ and $22 \mathrm{~cm}$ using the Abrams cone (see Figure 5).

Additionally, more tests were done using $450 \mathrm{Kg}$ of cement with a water/cement ratio of 0.45 and $100 \mathrm{Kg}$ of dredged material (mix C in Table 2). The percentage of arid was $56 \%$ and $44 \%$ of gravel.

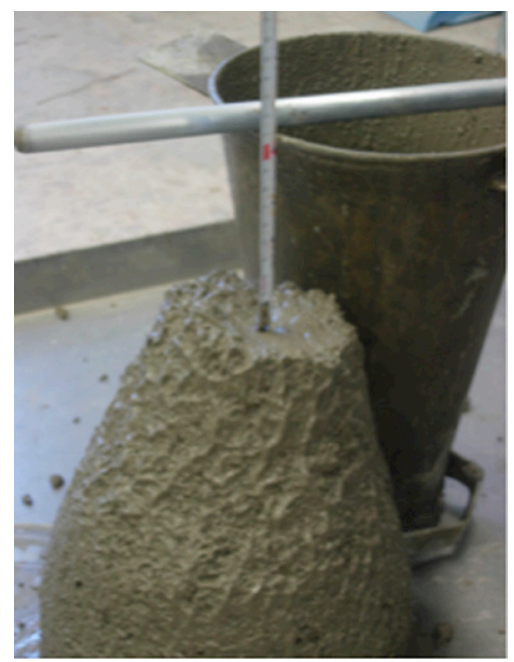

FIGURE 4. Aspect of the optimum mix using the sediment as substitution of fine aggregate.
This third mix contains $1.7 \%$ of different admixture so the concrete obtained was extremely cohesive and self-levelling with a spread diameter of $56 \mathrm{~cm}$. So, a self compacting concrete (SCC) was reached. Some pictures of this mix can be seen in Figure 6.

\section{Step 6: Characterization of the SCC produced}

\subsection{Fresh state}

The characterization of the fresh state of the SCC produced was performed by the determination of the consistency, air content, density and fluency. Results are given in Table 5.

\subsection{Hardened state}

The SCC produced with dredged sediments were tested after 28 days of curing in a humid chamber from a mechanical, environmental and durability point of view.

\subsubsection{Mechanical tests}

Compressive strength was measured over three concrete samples at the age of 28 days. Values obtained are those expected for a SCC developed with standard siliceous filler and they are given in Table 6.

\subsubsection{Environmental tests}

Even though the sediment was previously analysed and classified as Category I (31), leaching of the concrete samples, as concrete is the final material fabricated with the sediment, were carried out according EN 12457-2:2002 (40). This test is important in order to assure no leaching of hazardous metals in the final product. 

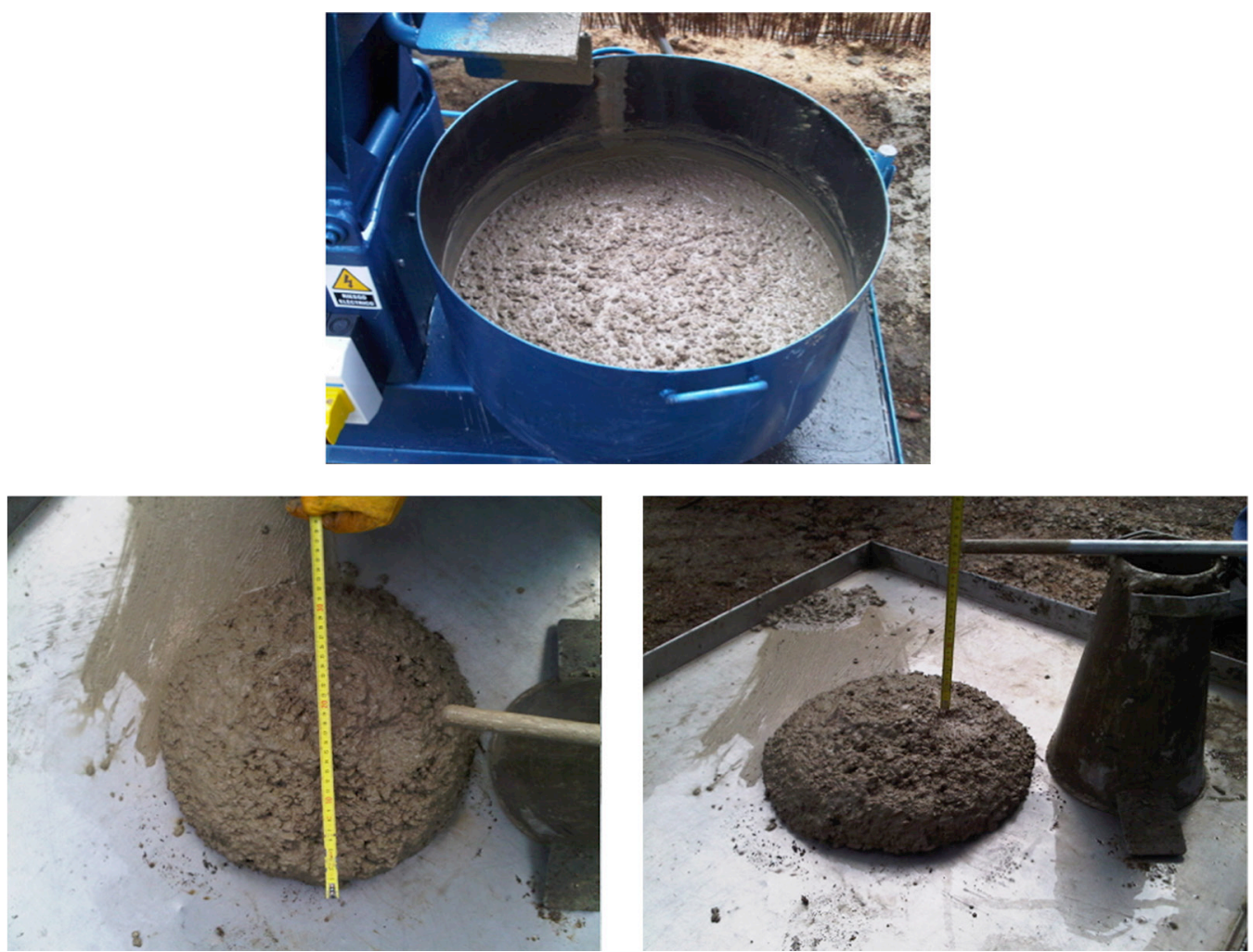

Figure 5. Aspect of mix 1 using the sediment as filler.

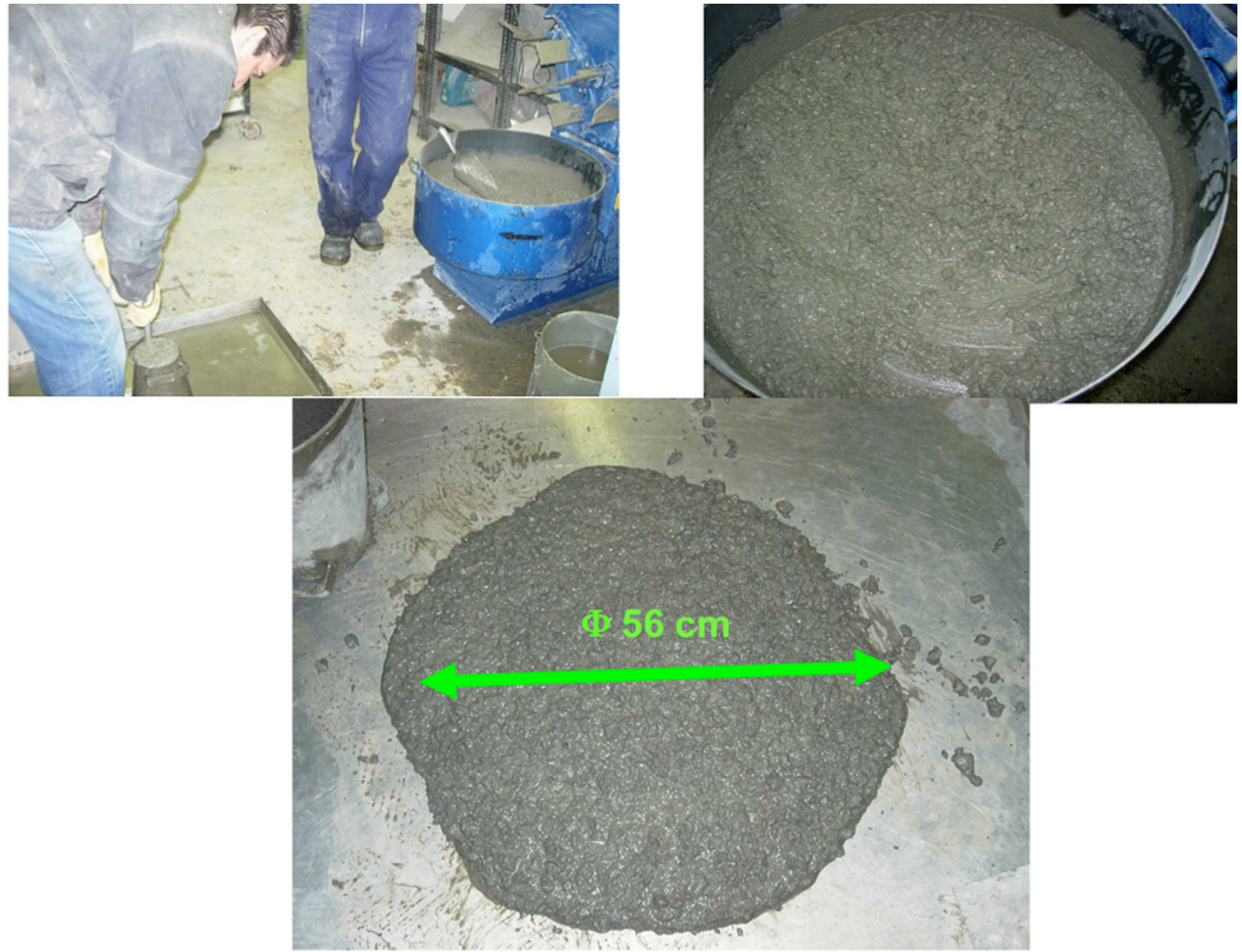

FIGURE 6. Aspect of mix 2 using the sediment as filler: SCC. 
TABLE 5. Characterization of the fresh state of the SCC produced with dredged sediments (mix C)

\begin{tabular}{lr}
\hline Air content $(\%)$ & 3 \\
Density $\left(\mathrm{g} / \mathrm{m}^{3}\right)$ & 2.23 \\
Spread diameter $(\mathrm{cm})$ & 56 \\
\hline
\end{tabular}

TABLE 6. Compressive strength at the age of 28 days (mix C)

\begin{tabular}{lc}
\hline Sample & Compressive strenght (Mpa) \\
\hline $\mathbf{1}$ & 43.8 \\
$\mathbf{2}$ & 45.1 \\
$\mathbf{3}$ & 43.7 \\
Average & 44.2 \\
\hline
\end{tabular}

TABLE 7. Results of the leaching tests

\begin{tabular}{lr}
\hline \multicolumn{2}{c}{ Leaching test } \\
\hline \% weight dry material & 94.8 \\
Conductivity after the filtration $(\mu \mathrm{S} / \mathrm{cm})$ & 8330 \\
Average temperature $\left({ }^{\circ} \mathrm{C}\right)$ & 20.8 \\
$\mathrm{pH}$ & 12.66 \\
Leaching $\mathrm{L} / \mathrm{S}(\mathrm{mL} / \mathrm{g})$ & 10 \\
Cadmium $(\mathrm{mg} / \mathrm{Kg})$ & $<0.01$ \\
Chromium $(\mathrm{mg} / \mathrm{Kg})$ & $<0.1$ \\
Lead $(\mathrm{mg} / \mathrm{Kg})$ & $<0.1$ \\
Copper $(\mathrm{mg} / \mathrm{Kg})$ & $<0.1$ \\
Nickel $(\mathrm{mg} / \mathrm{Kg})$ & 0.11 \\
Zinc $(\mathrm{mg} / \mathrm{Kg})$ & $<0.2$ \\
\hline
\end{tabular}

The results obtained, concerning heavy metals, $\mathrm{pH}$ and conductivity in the leachate, are given in Table 7 , where it can be seen that all data except nickel are below the detection limit of the analytical technique.

All the results of metal leaching expressed in Table 7 are under the limits established in the RD $1481 / 2001$, by which regulates waste disposal by landfill, considering its last modification published in the order AAA/661/2013. The following table shows the lixiviation limit values for waste acceptable at landfills for inert waste (Table 8).

These values shall apply to waste acceptable at landfills for inert waste, calculated in terms of total liberation for the ratios between liquid and solid (L/S) of $101 / \mathrm{kg}$ and directly expressed in $\mathrm{mg} / \mathrm{l}$. Calculated using the test method UNE-EN 12457/ Part $4(\mathrm{~L} / \mathrm{S}=101 / \mathrm{kg}$, particle size $<10 \mathrm{~mm})$.

\subsubsection{Durability tests}

Parameters obtained by mercury intrusion porosimetry (total porosity, average pore diameter and bulk density) are given in Table 9 , where it can be
TABLE 8. Lixiviation limit values for waste acceptable at landfills for inert waste according to the order AAA/661/2013

\begin{tabular}{|c|c|c|c|}
\hline Componen & & \multicolumn{2}{|c|}{$\mathrm{L} / \mathrm{S}=10 \mathrm{l} / \mathrm{kg}$ (mg/kg dry material) } \\
\hline As & & \multicolumn{2}{|l|}{0.5} \\
\hline $\mathrm{Ba}$ & & \multicolumn{2}{|l|}{20} \\
\hline $\mathrm{Cd}$ & & \multicolumn{2}{|l|}{0.04} \\
\hline Cr total & & \multicolumn{2}{|l|}{0.5} \\
\hline $\mathrm{Cu}$ & & \multicolumn{2}{|l|}{2} \\
\hline $\mathrm{Hg}$ & & \multicolumn{2}{|l|}{0.01} \\
\hline Mo & & \multicolumn{2}{|l|}{0.5} \\
\hline $\mathrm{Ni}$ & & \multicolumn{2}{|l|}{0.4} \\
\hline $\mathrm{Pb}$ & & \multicolumn{2}{|l|}{0.5} \\
\hline $\mathrm{Sb}$ & & \multicolumn{2}{|l|}{0.06} \\
\hline $\mathrm{Se}$ & & \multicolumn{2}{|l|}{0.1} \\
\hline $\mathrm{Zn}$ & & \multicolumn{2}{|l|}{4} \\
\hline Chloride & & \multicolumn{2}{|l|}{800} \\
\hline Fluoride & & \multicolumn{2}{|l|}{10} \\
\hline Sulphate & & \multicolumn{2}{|l|}{1.000} \\
\hline Phenol ind & & \multicolumn{2}{|l|}{1} \\
\hline Solved org & aic carbon (COD) & \multicolumn{2}{|l|}{500} \\
\hline Total solid & olved (STD) & \multicolumn{2}{|l|}{4.000} \\
\hline \multicolumn{4}{|c|}{$\begin{array}{l}\text { TABLE 9. Microstructural characteristics of the } \\
\text { SCC including dredged sediment (Mix C) }\end{array}$} \\
\hline & $\begin{array}{c}\text { Total porosity } \\
\text { (\% vol.) }\end{array}$ & $\begin{array}{l}\text { Average pore diameter } \\
(4 \mathrm{~V} / \mathrm{V})(\mu \mathrm{m})\end{array}$ & $\begin{array}{l}\text { Density } \\
\left(\mathrm{g} / \mathrm{cm}^{3}\right)\end{array}$ \\
\hline Sample 1 & 8.74 & 0.0437 & 2.269 \\
\hline Sample 2 & 9.64 & 0.0394 & 2.203 \\
\hline Average & 9.19 & 0.041 & 2.236 \\
\hline $\operatorname{COV}(\%)$ & 6.92 & 7.32 & 2.08 \\
\hline
\end{tabular}

noticed that the concrete presents an averaged total porosity of 9.19 ( $\%$ vol.), with a small average pore diameter (4V/A) and typical value of density for a SCC concrete.

Accumulated and differential pore size distribution of sample 1 is given in Figure 7, where it can be seen that the material presents a bi-modal distribution, with their highest maximum at around $0.08 \mu \mathrm{m}$ and the other around $3 \mu \mathrm{m}$.

X-ray diffraction tests were carried out on grounded samples of concrete. The diffraction patterns obtained indicated that with the exception of the positive identification of a silicate of $\mathrm{Fe}$ and $\mathrm{Mg}$, and a sulphate of $\mathrm{Fe}$ and $\mathrm{Ti}$, no differences with a conventional concrete designed with normal silica filler are found with no evidence of any harmful phase for this material.

Other indicator of concrete durability is the electrical resistivity, which was measured using a commercial resistivimeter. Values obtained in two 


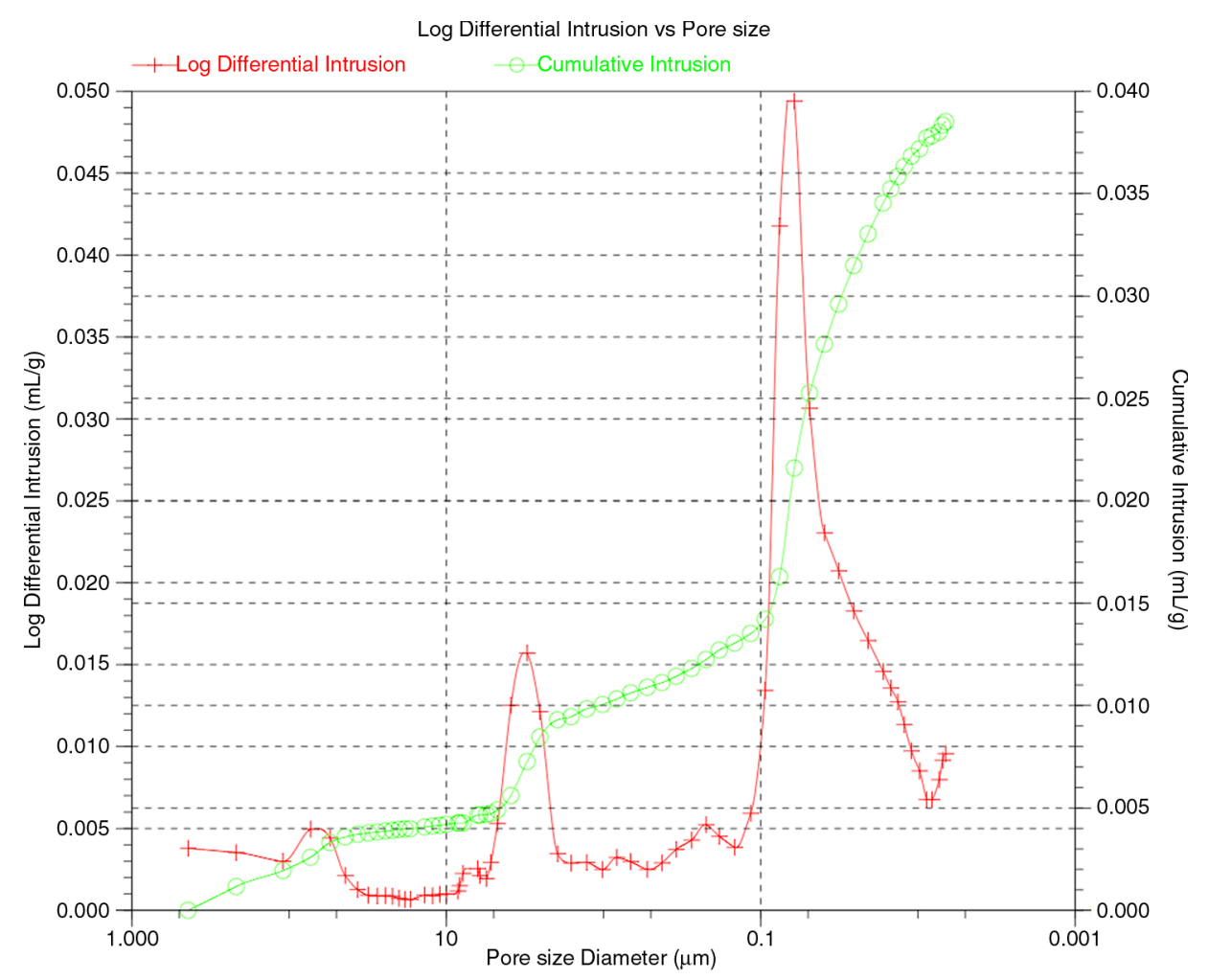

FIGURE 7. Accumulated and differential pore size distribution of one of the samples of SCC (Mix C).
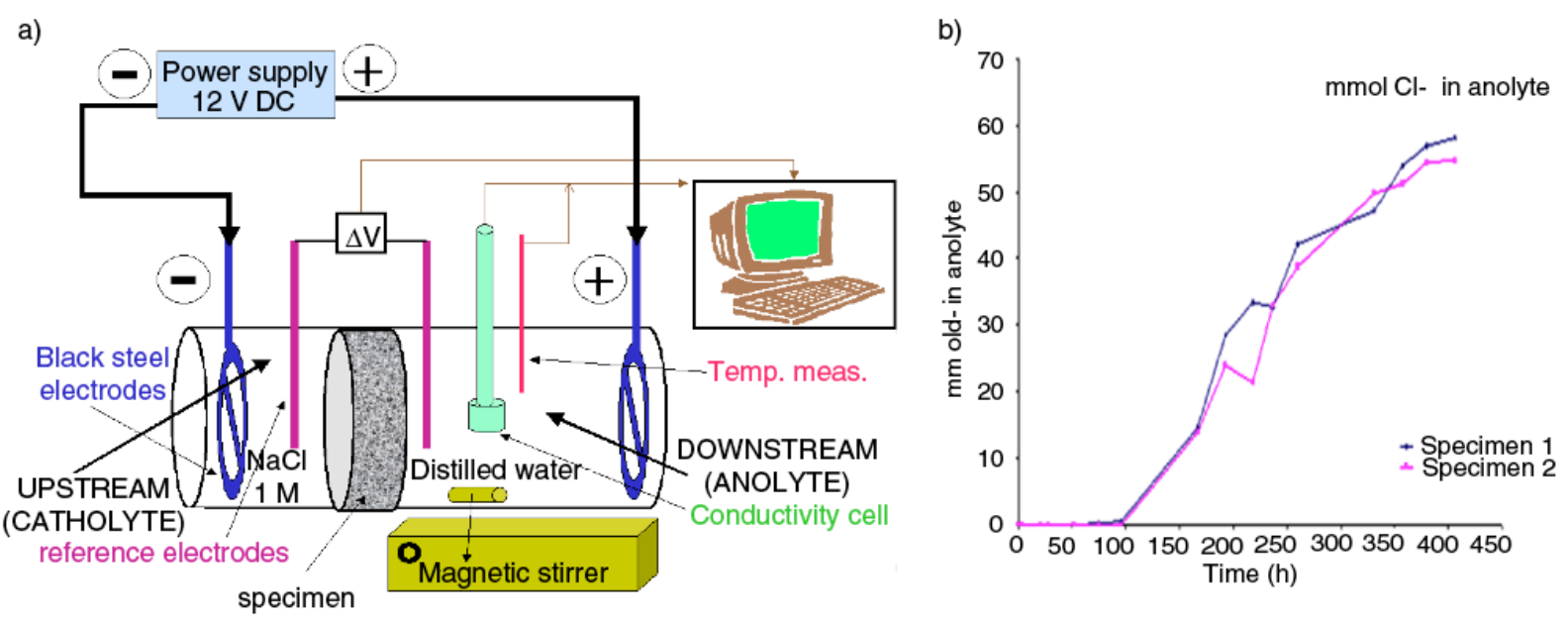

FIgURE 8. a) Schematic representation of the set up of the test. b) evolution of the accumulated $\mathrm{Cl}^{-}$in the anolyte.

specimens of concrete were, respectively, $49.4 \mathrm{~K} \Omega \mathrm{cm}$ and $49.15 \mathrm{~K} \Omega \mathrm{cm}$, corresponding to a high durability concrete.

The transport properties through the matrix were measured by means of the determination of the steady and non-steady state chloride diffusion coefficients and the capillary absorption. The determination of the steady and non-steady state chloride diffusion coefficients is based on the accelerated measurement of the amount of chlorides arriving to the anolyte because of a voltage drop applied to the system. 
Guidelines for assessing the valorization of a waste into cementitious material 11

In Figure 8-a, schematic representation of the set up of the test is presented. In Figure 8-b the evolution of the accumulated $\mathrm{Cl}^{-}$in the anolyte passing through the concrete is given.

From the representation in Figure 8-b, the effective and apparent diffusion coefficients can be determined. And from them, the binding factor of the material (alpha), supposed a linear binding. These results are given in Table 10.

The water take-up of hardened concrete was determined by capillary absorption. The water absorption of the two specimens of concrete, in percentage of weight, is presented as a function of the square root of the time in Figure 9, where it can be seen that the final absorption of the specimens is around $1.7 \%$ in weight of sample, which is quite low.

The summary of the parameters describing the capillary process is given in Table 11 .

Values obtained for the resistant of water penetration, capillary suction and effective porosity are similar for both samples, and are indicative of materials with good resistance to the penetration of water.

Results obtained in the durability tests have been evaluated according to the durability indicators described in "Concrete design for a given structure service life" (45). They are presented in Table 12.

The low porosity of the concrete and its high electrical resistivity are indicators of a high durability.

TABLE 10. Stationary, non stationary chloride diffusion coefficients and bindingfactor of the SCC (Mix C)

\begin{tabular}{lccc}
\hline & Ds $\left(\mathbf{c m}^{\mathbf{2}} \mathbf{l s}\right)$ & Dns $\left(\mathbf{c m}^{2} / \mathbf{s}\right)$ & alpha \\
\hline Specimen 1 & $1.21 \mathrm{E}-08$ & $8.28 \mathrm{E}-08$ & 0.146 \\
Specimen 2 & $1.03 \mathrm{E}-08$ & $1.09 \mathrm{E}-07$ & 0.094 \\
Average & $1.12 \mathrm{E}-08$ & $9.61 \mathrm{E}-08$ & 0.12 \\
Desv. & $1.24 \mathrm{E}-09$ & $1.89 \mathrm{E}-08$ & 0.0365 \\
COV (\%) & 11.073 & 19.623 & 30.366 \\
\hline
\end{tabular}

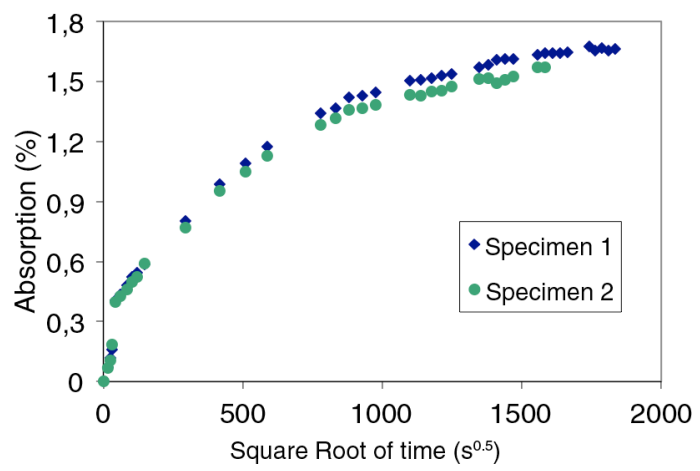

FIGURE 9. Water absorption of the two specimens of the concrete produced.
TABLE 11. Parameters describing the capillary process (Mix C)

\begin{tabular}{llllc}
\hline $\begin{array}{l}\text { Capilary } \\
\text { absorption }\end{array}$ & Sample 1 & Sample 2 & Average & COV (\%) \\
\hline $\mathrm{m}\left(\mathrm{s} / \mathrm{m}^{2}\right)$ & $7.14 \times 10^{8}$ & $7.17 \times 10^{8}$ & $7.15 \times 10^{8}$ & 0.4 \\
$\mathrm{k}\left(\mathrm{Kg} / \mathrm{m}^{2} \mathrm{~min}^{0.5}\right)$ & $1.46 \times 10^{-3}$ & $1.42 \times 10^{-3}$ & $1.44 \times 10^{-3}$ & 2.3 \\
$\left(\mathrm{Kg} / \mathrm{m}^{3}\right)$ & $3.91 \times 10^{-2}$ & $3.80 \times 10^{-2}$ & $3.85 \times 10^{-2}$ & 2.1 \\
\hline
\end{tabular}

TABLE 12. Potential durability according to "Concrete design for a given structure service life" (45)

\begin{tabular}{lcl}
\hline Potential durability indicator & $\begin{array}{c}\text { Experimental } \\
\text { SCC }\end{array}$ & $\begin{array}{c}\text { Average } \\
\text { values }\end{array}$ \\
\hline Total porosity & 9.19 & High-medium \\
Electrical resistivity $(\mathrm{K} \Omega \mathrm{cm})$ & 49.3 & High \\
Coefficient diffusion $(\mathrm{Ds})\left(\mathrm{cm}^{2} / \mathrm{s}\right)$ & $1.12 \mathrm{E}-08$ & Medium \\
Coefficient diffusion $(\mathrm{Dns})\left(\mathrm{cm}^{2} / \mathrm{s}\right)$ & $9.60 \mathrm{E}-08$ & Medium \\
\hline
\end{tabular}

However, values obtained in the measurement of the steady and non-steady diffusion coefficients indicate a moderated durability. Therefore, concerning environmental compatibility and durability, the main characteristics of the self compacting concrete developed are completely in agreement with those expected for a conventional concrete designed with normal silica filler.

\section{CONCLUSIONS}

In this paper, a feasibility protocol to assess the possibility of including a waste material in the production of a structural cementitious material has been designed. Then the protocol has been illustrated with its application to a real case: a dredged sediment of an Spanish harbour that has resulted feasible to be part of a self compacting concrete (SCC).

\section{ACKNOWLEDGMENTS}

This research was part of the project CLEAM CENIT sponsored by the Spanish Center for Development of Industrial Technology (CDTI) within the CENIT program and has been made possible owing the economic support from the CDTI and A.I.E. (Association of Economic Interest) CLEAM-CENIT. Special mention to DRAGADOS, that was the responsible of the industrial coordination of the task in which this work was developed.

The authors also thank the Ministry of Economy and Competitivity the funding provided through the project BIA 2011-25653 "TELEPASSCLOR" granted within the Spanish National Plan of $\mathrm{R}+\mathrm{D}+\mathrm{i}$. 


\section{REFERENCES}

1. Zaitri, R.; Bederina, M.; Bouziani, T.; Makhloufi, Z.; Hadjoudja, M. (2014) Development of high performances concrete based on the addition of grinded dune sand and limestone rock using the.mixture design modelling approach. Constr. Build. Mater. 60, 8-16. http://dx.doi.org/10.1016/j. conbuildmat.2014.02.062.

2. Yan, D.Y.S.; Tang, I.Y.; Lo, I.M.C. (2014) Development of controlled low-strength material derived from beneficial reuse of bottom ash and sediment for green construction. Constr. Build. Mater. 64, 201-207. http://dx.doi.org/10.1016/j. conbuildmat.2014.04.087.

3. Madurwar, M.V.; Ralegaonkar, R.V; Mandavgane, S.A. (2013) Application of agro-waste for sustainable construction materials: A review. Constr. Build. Mater. 38, 872-878. http://dx.doi.org/10.1016/j.conbuildmat.2012.09.011.

4. Hassan, I.O.; Ismail, M.; Noruzman, A.H.; Yusuf, T.O.; Mehmannavaz, T.; Usman, J. (2013) Characterization of some key Industrial Waste products for sustainable Concrete production. Eds. Liu XH, Zhang KF, Li MZ. Material Design, Processing and Applications, Parts 1-4, 1091-1094.

5. de Oliveira, L.A.P.; Gomes, J.P.C.; Nepomuceno, M.C.S. (2013) The influence of wastes materials on the rheology of rendering mortars. Applied Rheology 23 [1], 11.

6. Barreca, F.; Fichera, C.R. (2013) Use of olive stone as an additive in cement lime mortar to improve thermal insulation. Energy and Buildings 62, 507-513. http://dx.doi. org/10.1016/j.enbuild.2013.03.040.

7. Di Palma, L.: Mancini, D.; Medici, F. (2012) Lab Scale Granulation Tests of Artificial Aggregate Production from Marine Sediments and Industrial Wastes. Bosicon 2012: 3rd International Conference on Contaminated Sites Remediation 28, 199-204.

8. Valdes, A.J.; Martinez, C.M.; Romero, M.I.G.; Garcia, B.L.; del Pozo, J.M.M.; Vegas, A.T. (2010) Re-use of construction and demolition residues and industrial wastes for the elaboration or recycled eco-efficient concretes. Spanish Journal of Agricultural Research 8, 25-34. http://dx.doi. org/10.5424/sjar/2010081-1140.

9. Safiuddin, M.; Jumaat, M.Z.; Salam, M.A.; Islam, M.S.; Hashim, R. (2010) Utilization of solid wastes in construction materials. International Journal of the Physical Sciences 5, 1952-1963

10. Zdiri, M.; Abriak, N.E.; Ben Ouezdou, M.; Neji, J. (2009) The use of fluvial and marine sediments in the formulation of Roller Compacted Concrete for use in pavements. Environmental Technology 30, 809-815. http://dx.doi.org/ 10.1080/09593330902990097.

11. Knoeri, C.; Nikolic, I.; Althaus, H.J.; Binder, C.R. (2014) Enhancing Recycling of Construction Materials: an Agent Based Model with Empirically Based Decision Parameters. Jasss-the Journal of Artificial Societies and Social Simulation 17

12. Felekoglu, B. (2007) Utilisation of high volumes of limestone quarry wastes in concrete industry (self-compacting concrete case). Resources Conservation and Recycling 51, 770-791.http://dx.doi.org/10.1016/j.resconrec.2006.12.004.

13. Bignozzi, M.C.; Sandrolini, F. (2006) Tyre rubber waste recycling in self-compacting concrete. Cem. Concr. Res. 36, 735-739. http://dx.doi.org/10.1016/j.cemconres.2005. 12.011 .

14. Ho, D.W.S.; Sheinn, A.M.M.; Ng, C.C.; Tam, C.T. (2002) The use of quarry dust for SCC applications. Cem. Concr. Res. 32, 505-511. http://dx.doi.org/10.1016/ S0008-8846(01)00726-8

15. Sua-Iam, G.; Makul, N. (2013) Use of increasing amounts of bagasse ash waste to produce self-compacting concrete by adding limestone powder waste. Journal of Cleaner Production 57, 308-319. http://dx.doi.org/10.1016/j.jclepro. 2013.06.009.

16. Pereira-de Oliveira, L.A.; Nepomuceno, M.; Rangel, M. (2013) An eco-friendly self-compacting concrete with recycled coarse aggregates. Informes de la Construccion 65, 31-41. http://dx.doi.org/10.3989/ic.11.138.
17. Nascimento, F.; Gachet-Barbosa, L.A.; Lintz, R.C.C.; Seydell, M.R.R. (2013) Production of self-compacting concrete using rock breaking waste residues. Eds. Yu L, Guo WP, Sun M, He J. Current Trends in the Development of Industry, Pts 1 and 2, 157-162.

18. Krishnasami, R.; Malathy, R. (2013) Significance of blast furnace slag as coarse aggregate in self compacting concrete. Eds. Hou H, Tian L. Architecture, Building Materials and Engineering Management, Pts 1-4, 829-833.

19. Azeredo, G.; Diniz, M. (2013) Self-compacting concrete obtained by the use of kaolin wastes. Constr. Build. Mater. 38, 515-523. http://dx.doi.org/10.1016/j. conbuildmat.2012.08.027.

20. Gesoğlu, M.; Guneyisi, E.; Kocabag, M.E.; Bayram, V.; Mermerdas, K. (2012) Fresh and hardened characteristics of self compacting concretes made with combined use of marble powder, limestone filler, and fly ash. Constr. Build. Mater. 37, 160-170. http://dx.doi.org/10.1016/j. conbuildmat.2012.07.092

21. Valdez, P.; Barragan, B.; Girbes, I.; Shuttleworth, N.; Cockburn, A. (2011) Use of waste from the marble industry as filler for the production of self-compacting concretes. Mater. Construcc. 61, 61-76. http://dx.doi.org/10.3989/ mc.2010.55109.

22. Topçu, I. B.; Bilir, T.; Uygunoglu, T. (2009) Effect of waste marble dust content as filler on properties of selfcompacting concrete. Constr. Build. Mater. 23, 1947-1953. http://dx.doi.org/10.1016/j.conbuildmat.2008.09.007.

23. Kou, S.C.; Poon, C.S. (2009) Properties of self-compacting concrete prepared with recycled glass aggregate. Cem. Concr. Comp. 31, 107-113. http://dx.doi.org/10.1016/j. cemconcomp.2008.12.002

24. Nystroem, G.M.; Pedersen, A.J.; Ottosen, L.M.; Villumsen, A. (2006) The use of desorbing agents in electrodialytic remediation of harbour sediment. Science of the Total Environment 357, 25-37. http://dx.doi.org/10.1016/j.scitotenv. 2005.04.040.

25. Castellote, M.; Andrade, C.; Alonso, C. (2000) Electrochemical removal of chlorides - Modelling of the extraction, resulting profiles and determination of the efficient time of treatment. Cem. Concr. Res. 30 [4], 615-621. http://dx.doi. org/10.1016/S0008-8846(00)00220-9.

26. Rozas, F.; Castellote, M. (2012) Electrokinetic remediation of dredged sediments polluted with heavy metals with different enhancing electrolytes. Electrochimica Acta 86, 102-109. http://dx.doi.org/10.1016/j.electacta.2012.03.068.

27. Mulligan, C.N.; Yong, R.N.; Gibbs, B.F. (2001) Surfactantenhanced remediation of contaminated soil: a review. Engineering Geology 60, 371-380. http://dx.doi.org/10.1016/ S0013-7952(00)00117-4.

28. Castellote, M.; Ordóñez, M.; Andrade, C.; Zuloaga, P.; Navarro, M. (2011) Electrochemical treatment to condition contaminated EAFD as addition to immobilisation mortar in low level waste concrete containers. Corrosion Engineering Science and Technology 46 [2], 190-194. http:// dx.doi.org/10.1179/1743278210Y.0000000005.

29. Montero, N.; Belzunce-Segarra, M.J.; Gonzalez, J.L.; Menchaca, I.; Garmendia, J.M.; Etxebarria, N.; Nieto, O.; Franco, J. (2013) Application of Toxicity Identification Evaluation (TIE) procedures for the characterization and management of dredged harbor sediments. Marine Pollution Bulletin 71, 259-268. http://dx.doi.org/10.1016/j. marpolbul.2013.01.038.

30. Castellote, M.; Andrade, C.; Alonso, C. (2001) Measurement of the steady and non-steady-state chloride diffusion coefficients in a migration test by means of monitoring the conductivity in the anolyte chamber-Comparison with natural diffusion tests. Cem. Concr. Res. 31 [10], 1411-1420. http:// dx.doi.org/10.1016/S0008-8846(01)00562-2.

31. Spanish recommendations for the management of dredged material in the Spanish harbours. (1994) Centro de Estudios y Experimentación de Obras Públicas, Puertos del Estado, Madrid.

32. Casado-Martinez, M.C.; Buceta, J.L.; Belzunce, M.J.; Delvalls, T.A. (2006) Using sediment quality guidelines for dredged material management in commercial ports 
from Spain. Environment International 32, 388-396. http:// dx.doi.org/10.1016/j.envint.2005.09.003.

33. Casado-Martinez, M.C.; Buceta, J.L.; Forja, J.M.; DelValls, T.A. (2006) Interlaboratory assessment of marine bioassays to evaluate the environmental quality of coastal sediments in Spain. I. Exercise description and sediment quality. Ciencias Marinas 32, 121-128.

34. Casado-Martinez, M.C.; Forja, J.M.; DelValls, T.A. (2009) A multivariate assessment of sediment contamination in dredged materials from Spanish ports. Journal of Hazardous Materials 163, 1353-1359. http://dx.doi.org/ 10.1016/j.jhazmat.2008.07.106

35. UNE EN 12350-2:2006. Testing fresh concrete. Part 2: Slump test.

36. UNE EN 12350-8:2011. Testing fresh concrete - Part 8: Self-compacting concrete - Slump-flow test.

37. UNE EN 12350-6:2009. Testing fresh concrete - Part 6: Density.

38. UNE EN 12350-7:2001. Testing fresh concrete - Part 7: Air content - Pressure methods.
39. UNE-EN 12390-3. Testing hardened concrete - Part 3: Compressive strength of test specimens.

40. EN 12457-2:2002 Characterization of waste. Leaching. Compliance test for leaching of granular waste materials and sludges. One stage batch test at a liquid to solid ratio of $10 \mathrm{l} / \mathrm{kg}$ for materials with particle size below $4 \mathrm{~mm}$ (without or with size reduction).

41. UNE ENV 12506 Characterization of waste. Analysis of eluates. Determination of $\mathrm{pH}, \mathrm{As}, \mathrm{Cd}, \mathrm{Cr}(\mathrm{VI}), \mathrm{Cu}, \mathrm{Ni}, \mathrm{Pb}$, $\mathrm{Zn}, \mathrm{Cl}^{-}, \mathrm{NO}_{2}^{-}, \mathrm{SO}_{4}^{2-}$

42. ENV 13370:2001. Characterization of waste. Determination of Ammonium-N, AOX, conductivity, $\mathrm{Hg}$, phenol index, TOC, $\mathrm{CN}^{-}$easily liberatable and $\mathrm{F}^{-}$

43. UNE 89987:2009 Concrete durability. Test methods. Measurement of chloride diffusion coefficient in hardened concrete. Multiregime method.

44. UNE 83982:2008. Concrete durability. Test methods. Determination of the capillar suction in hardened concrete. Fagerlund method.

45. Spanish Code on Structural Concrete EHE-08. 